\title{
Article \\ Policy Support for Home Gardens in Vietnam Can Link to Sustainable Development Goals
}

\author{
Rachmat Mulia ${ }^{1}$, Tam Thi Le ${ }^{1, *}$, Nghia Dai Tran $^{2}$ and Elisabeth Simelton ${ }^{1}$ (i) \\ 1 World Agroforestry (ICRAF), Hanoi 10000, Vietnam; r.mulia@cgiar.org (R.M.); e.simelton@cgiar.org (E.S.) \\ 2 Institute of Policy and Strategy for Agriculture and Rural Development (IPSARD), Hanoi 10000, Vietnam; \\ trandainghia@ipsard.gov.vn \\ * Correspondence: 1.tam@cgiar.org; Tel.: +84-24-3783-4644
}

check for updates

Citation: Mulia, R.; Le, T.T.; Tran, N.D.; Simelton, E. Policy Support for Home Gardens in Vietnam Can Link to Sustainable Development Goals. Agriculture 2022, 12, 253. https:// doi.org/10.3390/agriculture12020253 Academic Editors: Martin Caraher, Cristina Santini and Alessio Cavicchi

Received: 29 December 2021

Accepted: 2 February 2022

Published: 10 February 2022

Publisher's Note: MDPI stays neutral with regard to jurisdictional claims in published maps and institutional affiliations.

Copyright: (C) 2022 by the authors. Licensee MDPI, Basel, Switzerland. This article is an open access article distributed under the terms and conditions of the Creative Commons Attribution (CC BY) license (https:// creativecommons.org/licenses/by/ $4.0 /)$.

\begin{abstract}
Despite research evidence on the diverse benefits of home gardens and their potential contributions to multiple sustainable development goals (SDGs), the role of policy towards supporting these contributions remains unclear in developing countries like Vietnam. In this study, we found that 25 out of Vietnam's 86 key rural development and agricultural policies enacted over the last decade (2010-2021) set specific targets for home gardens. The targets, however, focus strongly on income generation with indicators stipulating e.g., $50-80 \%$ of total income from home gardens should be generated by the main product. The policies set no specific target for other potential roles of home gardens beyond the economy of rural households and can exacerbate the widespread transformation of home gardens in Vietnam into farming practices with low crop diversity. The latter potentially limits contributions of home gardens to two (SDG 1, 10) of at least 11 (SDG 1-3, 5, 6, 8, 10-13, 15) of Vietnam's 17 SDGs. To narrow the gap between research and policy in home garden contributions to Vietnam's SDGs, we need to better mainstream integrated home garden systems and their diverse benefits, enrich policy targets beyond the income generation, and strengthen coordination among state departments for policy implementation.
\end{abstract}

Keywords: agroforestry; crop diversification; multi-functionality; plant genetic diversity; rural development

\section{Introduction}

Recent studies have drawn a connection between the socio-economic and ecological benefits of home gardens in rural areas of developing countries with potential contributions to sustainable development goals (SDGs) [1-3]. Home gardens refer to relatively small land areas around homesteads where diverse annual and perennial crop species are usually planted by the members of the household for supplementary sources of food and income [4-6]. The average land sizes of home gardens in rural areas of developing countries vary e.g., 400-6000 square meters in Indonesia [5,7] and 1400-7500 square meters in Vietnam $[5,8]$. Albeit relatively small in land size, rural home gardens can potentially contribute to poverty alleviation (SDG1), food and nutrient security (SDG2), healthy lives and wellbeing (SDG3), gender equality and empowerment (SDG5), sustainable consumption and production (SDG12), climate change mitigation (SDG13), and reduced land degradation and biodiversity loss (SDG15) [1-3].

Despite this abovementioned potential, widespread transformation of home gardens in developing countries into intensive monoculture farming still prevails, generating limited co-benefits apart from income [5,7-9]. For example, driven mainly by market opportunities, $85 \%$ of 95 surveyed households in West Java province of Indonesia converted their traditional home gardens into monocultures, with annual crops such as spring onions (Allium fistulosum) as the main crop [7]. This conversion has contributed to making spring onions the main commodity crop in the study site. In Vietnam, home gardens have been strongly 
affected by a series of land and market reforms promulgated in the late 1980s [8]. The reforms permitted private ownership of land and businesses, more liberated access to markets and investment, and encouraged farmers to cultivate commercial crops in their home gardens. For example, home gardens with monoculture longan (Dimocarpus longan) trees have become widespread in the southern part of Vietnam [8]. The transformation of home gardens into monocultures will seriously limit their diverse benefits $[7,10]$. In addition, home gardens (as verified in part of the current study) are invisible in the 2016-2022 United Nations' Decade on Nutrition, and are mentioned in only a handful of examples from the 2022-2030 Food Systems Summit solution cluster towards delivering on all SDGs in the Decade of Action initiative [11]. This indicates a gap between research and multilateral perspectives on home gardens' potential contributions to the SDGs.

Policy supports are needed to help ensure multi-functionality of home gardens $[7,8]$. Multi-functionality refers to potential concurrent roles of home gardens in: maintaining household food and nutrient security [1,4,12]; generating additional income [8,9,13-15] including for women [4,16-18], and uplifting women's status in the family or community thanks to their agronomic competency in managing home gardens $[4,17,19-21]$; generating ecological benefits through, e.g., regulating microclimates, sequestering carbon for greenhouse gas removal, and hosting rich agrobiodiversity [22-27] including native plant species, and playing a role as in situ conservation of genetic diversity in plants and endangered tree species $[24-26,28,29]$. In short, multi-functionality refers to the six key benefits of home gardens for income generation, food and nutrient security, gender equality, climate change mitigation, climate change adaptation, and biodiversity conservation $[4,22,27,30]$.

Over the past decade, several Asian developing countries such as Sri Lanka and Vietnam have promulgated home garden policies $[4,29,31,32]$. There is, however, no study investigating the focus of the policies and, therefore, the benefits that can be generated by future home gardens in the countries are unclear. Studies have shown that traditional home gardens in the developing countries often feature a high crop diversity in contrast to other agricultural land uses dominated by common annual crop species such as paddy or maize or perennial crop species such as fruit or timber trees [5,6,20,33,34]. Rural households usually manage home gardens for subsistence or generating additional income $[4,5,14]$. The crop diversity in home gardens can, however, generate a substantial income and diverse benefits. For example, home gardens with pomelo (Citrus maxima), orange (Citrus sinensis), or other fruit tree species in different regions of Vietnam could generate income that contributed up to $60 \%$ of total family income $[5,8]$. The systems also accommodated food crops such as rice, maize, or sweet potatoes for family consumption, and fibers, timbers, fodder, fuelwoods, or medicinal herbs [8,9,35-39]. Some home gardens had fishponds of 72-1500 square meters in size as a source of protein, and water for different purposes such as irrigation, animal consumption, and household needs [5,36]. Home gardens with vertical crop stratification systems can protect households from strong winds or intense drought or heat through shades and improved micro-climate [35,36,38,39]. Traditional home gardens might accommodate native and endangered tree species. For example, a critically endangered (Aquilaria crassna) and two endangered (Erythrophleum fordii and Parashorea chinensis) species based on the global Red List of threatened tree species (http: / / www.iucnredlist.org/ accessed on 21 September 2017) were found in home gardens in the North East and North Central Coast region of Vietnam [29]. Trees in home gardens can store a substantial biomass. For example, the aboveground biomass of fruit treebased home gardens in Northwest Vietnam could reach 250 tonnes $\mathrm{CO}_{2}$ equivalent per hectare [40]. Furthermore, the tasks of managing home gardens which accommodate a high crop diversity are often shared between Vietnamese men and women within families [8,9]. Women usually manage crops for food and nutrient security $[8,9]$. The focus of home garden policies in the developing countries will determine the diversity and extent of benefits that can be derived from home gardens. The high proportion of rural to total population in Asian developing countries such as Sri Lanka, Nepal, or Vietnam that ranged between $60-82 \%$ in 2020 [41] suggests that millions of people could be affected by the 
implementation of the home garden policies. For example, the rural population in Vietnam was about 61 million people in 2020 [42].

The absence of study on the focus of the policies also hampers further analysis on policy support for potential contributions of home gardens to national programs in the developing countries such as Vietnam's SDGs. Vietnam's 17 SDGs were declared in 2017 and mirror the 17 global SDGs, specifying 115 targets adapted to the country's context and priorities [43]. An in-depth study on home gardens' potential contributions to Vietnam's SDGs is absent from the literature. However, mapping between research evidence on benefits from home gardens in Vietnam and the targets of Vietnam's SDGs exists (unpublished data from the World Agroforestry) as described in Table A1 (Appendix A). The mapping indicates that home gardens can potentially contribute to at least 11 out of Vietnam's 17 SDGs, namely SDG 1-3, 5, 6, 8, 10-13, and 15, and to 23 of their 78 targets. A similar mapping for Indian home gardens added SDG 4 to the list but excluded SDG 6, 10 and 15 [1]. A similar effort for the context of smallholder farming excluded SDG 6 and 11 [44]. Vietnamese home gardens can potentially contribute to SDG 6 because some systems such as the garden-pond-livestock pen (or vươn-ao-chuồng in Vietnamese) have fishponds $[5,36]$ that provide water for farm and household needs.

The objective of this study was to investigate the focus of Vietnam's rural development and agricultural policies enacted over the last decade (2010-2021) to inform their support of home garden multi-functionality that further determines potential contributions to multiple SDGs. We focused on Vietnam because more home garden policies have likely been enacted in the country following the declaration by the Deputy Prime Minister at the national congress in 2018 (Declaration 173/TB-VPCP issued on 5 October 2018) on the need to improve rural development and home garden demonstration models. The study also identifies the current gap between research and policy in potential contributions of home gardens to Vietnam's SDGs. The results figure out home gardens' benefits that are strongly or little addressed in the policies and will provide recommendations to ongoing national review processes of rural development and agricultural policies in Vietnam for the period up to 2030. In addition, the approach can provide guidance for potential applications in other developing countries wherein a gap in research and policy on the values of home gardens likely exists.

\section{Materials and Methods}

\subsection{Overview of the Methodology}

The study was conducted in three steps (Figure 1) and according to our knowledge, a similar approach is absent in the literature. The first step involved isolating policies that set specific targets for home gardens among Vietnam's rural development and agricultural policies. We considered these as home garden policies. We subsequently investigated the focus of the home garden policies based on their targets and indicators (step 2a) and provided supports (step 2b). Finally, using the results from step 2, we assessed the gap between research and policy in the potential contribution of home gardens to Vietnam's SDGs. Each step is described in detail below.

\subsection{Step 1. Isolate Home Garden Policies from Rural Development and Agricultural Policies}

Based on consultations with experts from the Institute of Policy and Strategy for Agriculture and Rural Development of Vietnam, policies relating to home gardens were found among those issued under the New Rural Development Programs (NRDP) (also known as Nông thôn mới in Vietnamese) or the National Agriculture Restructuring and Development of Other Agriculture Programs (NARDAP) (Tái cơ cấu nông nghiệp quốc gia và các chính sách hỗ trợ phát triển nông nghiệp khác). Both have been the main programs for implementing Vietnam's rural development strategies. Vietnam has implemented two NRDPs through Decision QĐ 800/2010/QĐ-TTg for the period of 2010-2015 and Decision QĐ 1600/2016/QĐ-TTg for 2016-2020. The two aimed at improving rural income and safeguarding natural resources and the environment. The NARDAP has been in place 
since 2013 through Decision QĐ 899/2013/QĐ-TTg to support the agriculture sector's restructuring. There have been 14 key national and 72 key provincial policies under NRDP and NARDAP enacted since 2010. We first classified the 86 policies into two groups, namely those mentioning or those never mentioning home gardens. To do this, we used the search term vươn ('garden' in English), and since there is no synonym for the word vươn in the official Vietnamese language, it is certain that policies never mentioning vườn never mention home gardens. We eventually verified the targets of the policies that mention home gardens and isolated those setting specific targets for home gardens. Those mentioning home gardens but without specific targets for them were not considered as home garden policies.

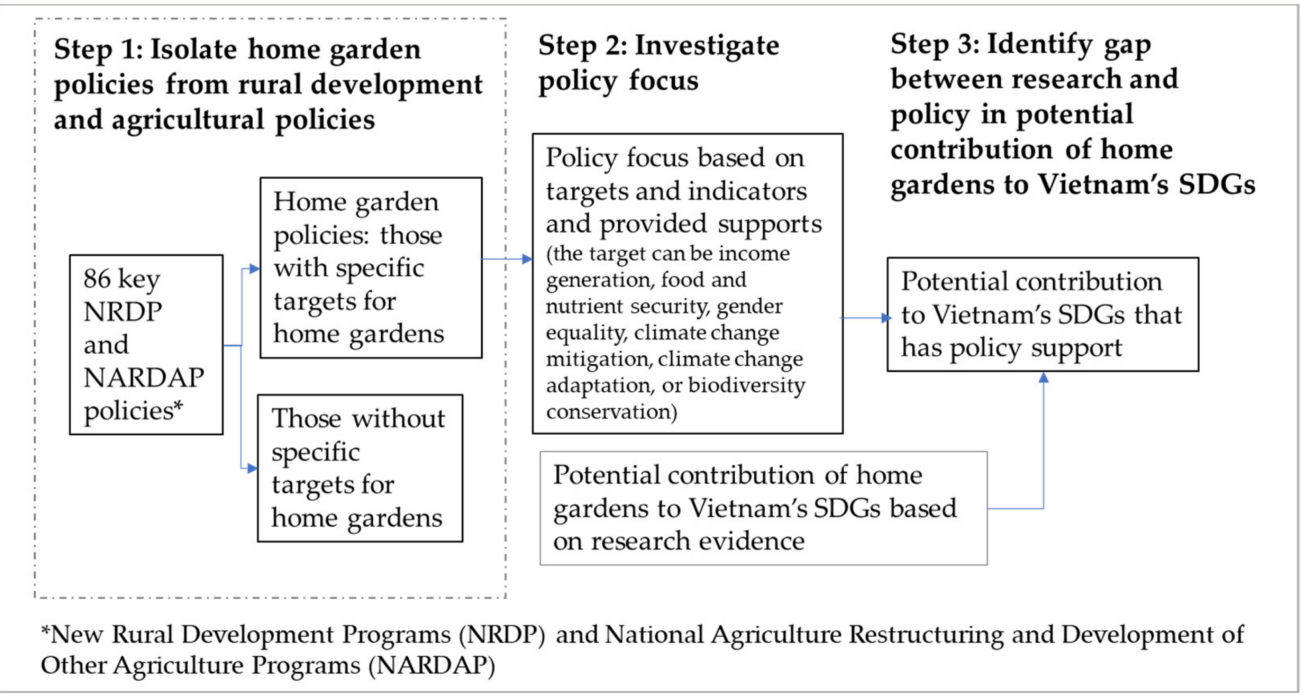

Figure 1. Three-step policy review in this study.

\subsection{Step 2. Investigate Policy Focus}

To figure out if the current policies support home garden multi-functionality, we investigated if the targets of home garden policies are associated with income generation, food and nutrient security, gender equality, climate change mitigation, climate change adaptation, or biodiversity conservation; namely, as described earlier, the six key benefits of home gardens highlighted in the literature (Step 2a). These benefits also determine if an agriculture or food system can combat dual challenges of food insecurity and climate change $[45,46]$. Based on studies $[4,22,27,30]$, the following serves as guidance for identifying relevant policy targets:

Income generation: improvement in household income through developing home gardens.

Food and nutrient security: improvement in household food and nutrient security through, e.g., increasing home garden food production or production of nutritious crops.

Gender equality: advancing the gender agenda, e.g., higher involvement of women in decision making related to crop selection for home gardens or agricultural activities.

Climate change mitigation: reducing greenhouse gas emission or increasing sequestered carbon in home gardens for greenhouse gas removal.

Climate change adaptation: increasing resilience of rural households to climate change through, e.g., introducing drought-tolerant crop species or varieties, promoting integrated systems such as agroforestry-based home gardens to modify micro-climate, or infrastructure development, e.g., better water storage or irrigation systems.

Biodiversity conservation: policy that targets, e.g., crop diversification or domestication of native tree species in home gardens for genetic conservation of plants.

In step 2a, we also identified targets with or without indicators, and policies that have several targets. For example, they might target income generation and use annual income per unit area of home garden as an indicator, while also targeting improvement in food 
and nutrient security without specifying an indicator. Hereafter, we refer to targets with indicators as "main targets" and those without as "secondary targets". We considered the former as the focus of the policies because policy implementation and funding often focus on achieving the targets with clear indicators.

In step $2 b$, we identified a variety of supports provided by the policies. These supports also reflect policy focus because they are tools for achieving the targets [47-49]. In Vietnam, policy support for smallholder farmers are in the form of, e.g., free planting materials or financial assistance to adopt new technologies that are important for agricultural development $[47,50,51]$.

\subsection{Step 3. Identify the Gap between Research and Policy}

Finally, using the synthesis of policy review and research evidence that indicate the potential contributions of home gardens to Vietnam's SDGs (Table A1), we identified contributions that are supported by policy.

\section{Results}

\subsection{Home Garden Policies Enacted over the Last Decade}

We found 25 home garden policies (Table 1), all of which are provincial-level policies and 13 (or 52\%) of them were enacted in 2019, likely as a response to the Deputy Prime Minister's declaration in 2018. A similar trend was found in the NRDP and NARDAP policies that include the home garden policies, in which 30 out of 86 policies were enacted in 2019. A list of the 25 home garden policies is provided in Table A2 (Appendix A).

Table 1. Number of home garden policies enacted over the last decade.

\begin{tabular}{ccc}
\hline Year & NRDP and NARDAP Policies * & Home Garden Policies \\
\hline 2013 & 1 & \\
2014 & 1 & 2 \\
2015 & 5 & \\
2016 & 11 & 1 \\
2017 & 9 & 6 \\
2018 & 12 & 13 \\
2019 & 30 & 3 \\
2020 & 12 & 25 \\
2021 & 5 & 25 \\
Total & 86 & \\
\hline
\end{tabular}

* New Rural Development Programs (NRDP) and National Agriculture Restructuring and Development of Other Agriculture Programs (NARDAP) that include home garden policies.

\subsection{Policy Targets and Indicators}

All the home garden policies describe income generation as a target (Figure 2). Out of the 25 in total, 21 set this as their main target. The other four policies do not have any main target due to the absence of any indicator. No policy targets gender equality, climate change mitigation, or biodiversity conservation. All the 21 policies only set income generation as the main target except Decision QĐ 25/2018/QĐ-UBND on new and improved rural standards for Thanh Hoa province for the period of 2018-2020, which also targets 30\% of home gardens in the province having irrigation systems. Based on the guidance from step 2 , this target is related to climate change adaptation. 


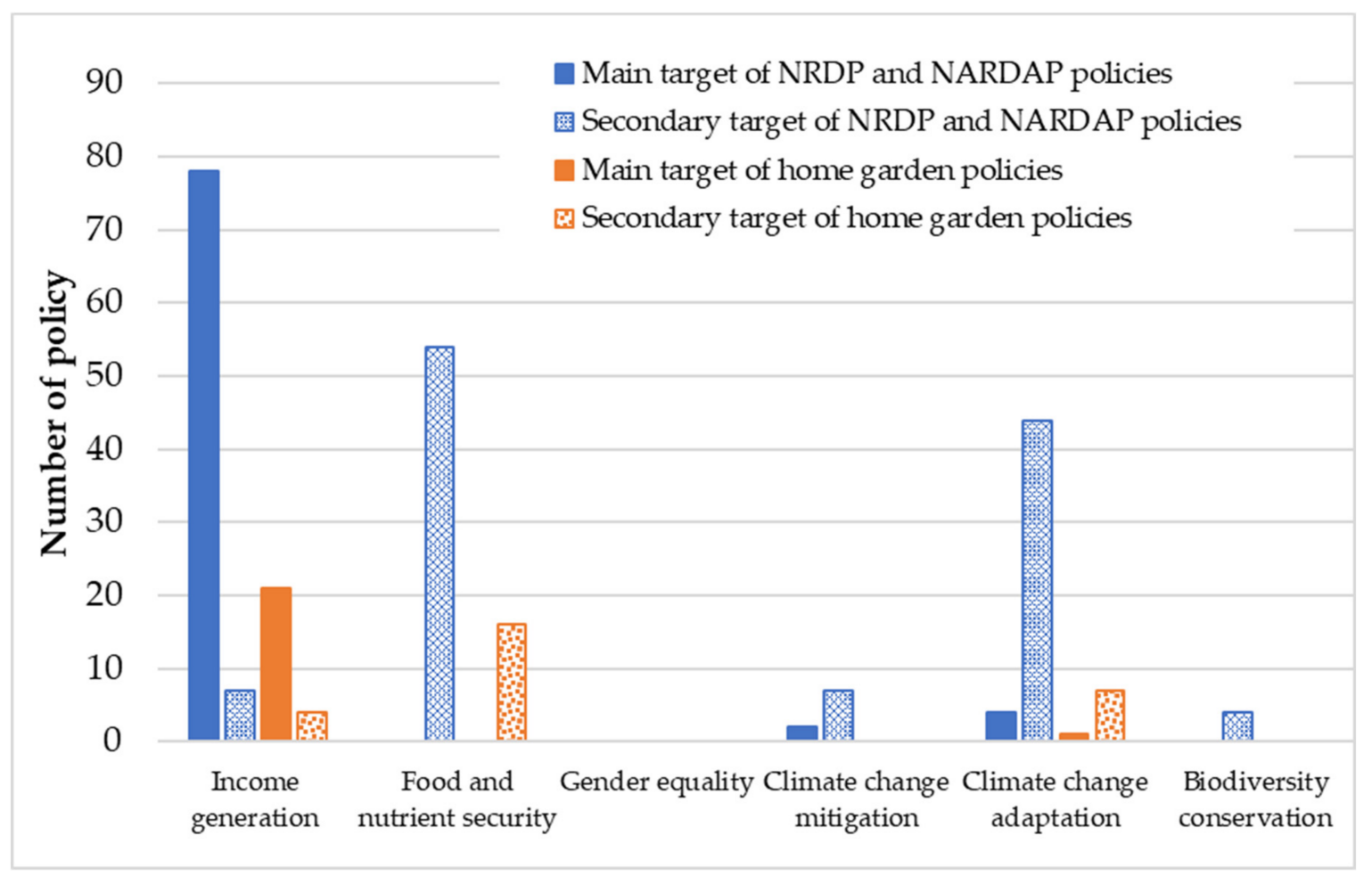

Figure 2. Main and secondary targets of the reviewed policies (the New Rural Development Programs (NRDP) and National Agriculture Restructuring and Development of Other Agriculture Programs (NARDAP) policies include home garden policies).

There are four different indicators that the policies use to measure income. The first is the level of income relative to that from paddy rice in the same year of observation. The policies generally set the objective of 3-5 times higher income from home gardens than that from paddy rice (Table A3, Appendix A). The second measures the share of income from the main home garden product to the total income obtained by a home garden. The share is targeted to range between $50-80 \%$. The third is annual income by home garden size. The common target for home gardens with land sizes less than or equal to 1000 square meters is VND 40-60 million (or USD 1739-2608 with an exchange rate of VND 23,000 for USD 1). Table A3 describes targets for larger home garden sizes. Some policies, such as Decision QĐ 373/2019/QĐ-UBND for Binh Dinh province, set an income target per 1000 square meters for different land sizes. The fourth is income per capita and most of the policies that employ this indicator compare it with target incomes set in the regulation on new rural standards. The income standard varies across regions in Vietnam (e.g., described in Decision QĐ 1980/2016/QĐ-TTg on indicators for the new rural standard of Vietnam's communes for the period of 2016-2020) with USD 1956 per capita as a national standard. The home garden policies generally target income per capita towards being 1.1-1.5 times higher than the income standard. In addition to the four key indicators, one policy, namely Decision QĐ 11/2018/QĐ-UBND that supports the development of new rural areas in Bac Giang province, targets $<5 \%$ poverty rate as a community-level indicator.

\subsection{Supports Provided by Home Garden Policies}

All the 25 home garden policies only provide supports for farmers, either individual farmers, farmer's groups, or cooperatives. The supports, either in cash or in kind, apply through two different mechanisms (Table A4, Appendix A): if farmers agree to cultivate crop species or develop home garden models specified by the policies, or they can propose any crop species, home garden model, or activity to improve crop production or product quality to the People's Committee at the community level and will receive support if their proposal is approved. Most of the policies offer the latter mechanism (Table A4). 
Related to the "any home garden model" that farmers can propose, the policies underline that the model must aim towards improving income or product quality and minimizing any negative impact on the environment. No elaboration on the "negative impact on environment" is, however, provided. The variety of supports also indicates that the home garden policies focus on income generation. Several (6 out of 25 ) home garden policies set a minimum land size as an additional condition to receive support. The size ranges from 300 to 1000 square meters.

\subsection{The Research and Policy Gaps in Home Garden Contributions to Vietnam's SDGs}

The potential contribution of home gardens to reducing poverty and sustaining rural income (SDG1 Target 1.1, SDG10 Target 10.1 and 10.2, refer again to Table A1) has strong policy support because all 25 home garden policies target income generation. Contributions beyond the economy of rural households such as maintaining food and nutrient security, and reducing maternal and child deaths (SDG2, SDG3), enhancing resilience to climate change, and extreme weather events (SDG11, SDG13), ensuring gender equality (SDG5, SDG8), and in situ conservation of genetic diversity to include native and endangered plant species (SDG2, SDG15), however, have limited or no policy support.

Beyond the 25 home garden policies, there are eleven policies that mention home gardens without specifying targets for them. Of which, there are two that have targets other than income generation, namely Decision QĐ 819/2016/QĐ-BNN-KHCN which contributes to the action plan of the agriculture and rural development sector's response to climate change for the period of 2011-2015 and vision to 2050, and Decision QĐ 524/2021/QĐTTg approving a proposal to plant one billion trees in the period of 2021-2025. Both are national policies that describe climate change adaptation as the main target. The former supports a variety of integrated systems such as: the garden-pond-livestock pen (or, as mentioned earlier, vườn-ao-chuồng in Vietnamese, as used in the policy) which is a traditional Vietnamese home garden model integrating fruit or timber trees, annual crops, aquaculture, and livestock; climate-smart agriculture (nông nghiệp thông minh với khí hạu); ecosystem-based adaptation (thích úng dưa vào hệ sinh thái), and agroforestry (nông lâm kêt $h o ̛ ̣$ ). The latter policy supports tree planting programs, especially those promoting "native, woody, multi-purpose tree species with environmental protection values, precious and rare tree species, and those bearing local, regional, or national cultural identities". Furthermore, there are two other policies that have main targets other than income generation, but they do not mention home gardens. Both are also national policies and were enacted just recently in 2021, specifically, Decision QĐ 1055/2020/QĐ-TTg issuing the national plan to respond to climate change for the period of 2021-2030, with a vision to 2050, and Decision QĐ 1658/2021/QĐ-TTg approving the national strategy on green growth for 2021-2030, with a vision to 2050 . The two policies set climate change adaptation and climate change mitigation as the main target, respectively. All four of these national policies clearly need to be translated towards provincial-level policies that mention, set specific targets for, and support home gardens.

\section{Discussion}

Other studies have also reported that most rural development and agricultural policies in Vietnam have been prioritizing production and income generation [52,53]. Such policy orientation has encouraged land expansion and intensification and other means of boosting production [52]. Co-benefits beyond the economy of rural households that can potentially be achieved using crop diversification have been little addressed in most of Vietnam's agricultural policies [52,54]. The policy focus on production and income generation has also exacerbated income inequality within rural areas and concerns over food safety driven by intensive chemical inputs to pursue higher production [55-58]. Future agricultural policies in Vietnam clearly need to pay more attention to product quality, safety, and added values, as well as resource efficiency, reduced waste, and resilience to economic and environmental shocks including climate change [52,56-58]. 
Likewise, home garden policies should not focus primarily on income benefits because rapid population growth and limited land in rural areas have also called for advancing the role of home gardens in sustaining social and environment benefits, apart from income generation [59-61]. Therefore, home garden models featuring crop diversification and biodiversity conservation should be promoted to reconcile multiple benefits $[6,14,24,28,31,62]$. The multi-functionality of home gardens mainly depends on the level of crop diversification and biodiversity $[6,24,33]$. Decision makers and other stakeholders in Vietnam likely need to be better informed on the critical role of home gardens in genetic conservation of plants. Home gardens can help preserve local varieties of different crop species as well as knowledge related to their origin, production, and propagation from generation to generation $[10,29,62]$. This indicates that, albeit relatively small in land size, the preservation, utilization, and management of species in home gardens can have wide and important applications [6].

All the 22 home garden policies enacted in or after 2018 (refer again to Table 1) were likely inspired by a successful implementation of a home garden program in Ha Tinh province of North Central Coast Vietnam regulated through the Decision QĐ 59/2015/QĐUBND. The program was the province's initiative and aimed at providing contribution to the achievement of income target set in Vietnam's New Rural Development Program. Vietnam's Deputy Prime Minister, through the 2018 national congress, encouraged other provinces to implement a similar home garden program. This can partially explain the fact that the 22 policies also focus on income generation. Some studies underlined challenges in integrating climate issues into Vietnam's agricultural policies $[63,64]$. The studies identified several barriers for such integration that might also explain the absence of home garden policies with focus beyond income generation. The challenges include a weak inter-ministry or department collaboration and information sharing, poor involvement of non-leading ministries or departments in policy formulation, and unclear guidelines for policy extension from national into provincial level $[63,64]$. It can also be the case that policy makers in Vietnam prioritized income generation for a dual purpose, namely, to reduce poverty and incidence of food and nutrient insecurity. Studies on smallholder farming in developing countries have demonstrated that such a dual objective can be achieved $[44,65,66]$. The studies provided evidence that smallholder farmers used additional farm income to afford more versatile and healthy diets. This might explain the fact that 16 out of 25 home garden policies mention food and nutrient security without specifying any target and indicator (refer again to Figure 1). We could not find any study on home gardens or smallholder farming in developing countries demonstrating a clear impact of increase in farm income on the other four key benefits apart from the food and nutrient security. The number of Asian developing countries that have addressed the multiple benefits of home gardens in their agricultural policies is limited. While policy support to halt the widespread transformation of traditional home gardens into monoculture cropping practices is still weak in Indonesia [7], the Sri Lankan government through the 2016-2018 Food Production National Program [67] promotes integrated farming practices in home gardens to optimize "horizontal and vertical spaces". As mentioned earlier, in Vietnam, the national policy QĐ 819/2016/QĐ-BNN-KHCN mentions home gardens (although without specific targets for them) and supports a variety of integrated systems for climate change adaptation. Vietnam's future rural development and agricultural policies must use this policy as an example or extend it into provincial-level policies that target home gardens and provide more support for such integrated systems that can potentially generate multiple benefits, not limited to income benefits or climate change adaptation. For example, depending on the crop species diversity, density, and ages, fruit tree-based agroforestry systems in Vietnam, including those developed in home gardens, can sequester 20-250 tonnes of aboveground $\mathrm{CO}_{2}$ equivalent per hectare [40]. These systems can accommodate more than ten fruit tree species of different densities and ages as well as diverse annual crop species for different purposes [40]. Several studies provided examples of agroforestry-based home garden systems in Vietnam that integrate commercial crops such as fruit or nut trees, coffee, black 
pepper, food and nutritious crops, and practices such as vermiculture or bee keeping [40,68]. Furthermore, technical guidelines for establishing and maintaining agroforestry systems in Vietnam's socio-economic and ecological context are also available e.g., [69-72].

To narrow the gap between research and policy as well as actions in home garden contributions to Vietnam's SDGs, some recommendations that can be used as guidelines for the review process of Vietnam's rural development and agricultural policies that lead up to 2030 include: (1) promulgate provincial-level policies as extensions to the national policies that have main targets other than income generation and then set specific targets for home gardens with suitable indicators. The targets and indicators can help ensure that the policy implementation and funding also prioritize home gardens. The fact that the recent policies, especially those enacted in 2021, have more diverse targets besides income generation, likely indicates an appropriate response from Vietnam's decision makers to other challenges, especially climate change, which Vietnam needs to address using rural development and agricultural policies. The other challenges affect outcomes of poverty reduction programs; (2) better mainstreaming of the potential socio-economic and ecological benefits of home gardens to decision makers and other stakeholders in Vietnam and encouraging the development of integrated home garden systems that feature crop diversification that can help generate diverse benefits, not only within rural homesteads. Vietnam can likely emulate Sri Lanka's 2016-2018 Food Production National Program that implemented a national awareness program on home garden benefits and supported the development of integrated farming practices and crop diversification in home gardens of rural, periurban and urban areas, schools, army camps, etc.; and (3) utilize existing or new research evidence to enrich future rural development and agricultural policies with diverse and feasible targets beyond the economy of rural households, as well as strengthen coordination among state departments for policy implementation and achievement of the targets. The strengthened interaction and coordination among the departments can also help set feasible targets and select suitable indicators. In addition, the literature has provided examples of indicators for the diverse benefits of home gardens. For instance, in relation to food and nutrient security, the production of grains (apart from rice), vegetables, and fruits as the main sources of food and nutrition that can be generated from home gardens, and the score of dietary diversity that represents a family's consumption of various crops can be used as indicators [73]. For gender equality, indicators that relate to the five domains of women's empowerment in agriculture exist [74,75]. The five domains include decisions on agricultural production, access to and decision-making power over productive resources, and control over use of generated income. Those indicators can also be used to calculate the Women's Empowerment in Agriculture Index [74,75] that can measure women's intrahousehold empowerment relative to men [73]. Several studies [73,76-79] describe indicators for sustainable agriculture or agroecological systems either at the farm or community level that can be selected to describe other key benefits of home gardens such as climate change mitigation and biodiversity conservation. Furthermore, the suggested studies associate these indicators with the SDGs.

Finally, it is worthwhile to note that the current study has insufficiently addressed the issue of interrelation among the six key benefits. Evidence on such interrelation is limited in the literature, especially under the context of Vietnamese home gardens. For the latter, we only found two studies reporting that improved nutrient sources in home gardens could affect farm income in two ways: first, nutritious crops provided protein and vitamins and could increase the productivity of family labor who managed cash crops in home gardens [80], and second, food and nutritious crops enabled rural families to reduce expense for versatile and nourishing diets and therefore, increased net income from the home gardens [8]. Under the context of smallholder farming in developing countries, apart from the interlinkage between income and food and nutrient security, gender equality or resilience to climate change has been known to improve farm productivity and income $[17,18,44,81,82]$. Related to gender equality, an increase in women's control over natural resources and land led to a higher farm production and 
income $[17,18]$. The lack of evidence on interrelation among the six key benefits of home gardens clearly calls for further research. In addition, important issues such as potential social and environmental impacts of policies supporting the cultivation of commercial crop species in home gardens have likely been understudied. Most of the supported crop species were those considered as the flagship products of the provinces (refer again to Table A4) and were associated with the One Commune One Product (OCOP) program. The latter aims at boosting rural economy through promoting local agricultural and nonagricultural products and has substantially improved household income, encouraged the development of local food industries, and increased employment opportunities in rural areas of Vietnam [83,84]. While the economic impacts of the program have been clear, possible social and environmental impacts on rural families and communities that relate to, e.g., gender equality and health risks due to an intensified use of agricultural chemical inputs in a proximity to human dwellings, have not been properly studied.

\section{Conclusions}

While the scientific literature on home gardens can demonstrate contributions to at least 11 out of Vietnam's 17 SDGs, Vietnam's current home garden policies, as reflected by their targets, indicators, and provided supports, focus strongly on income generation (SDG 1, SDG 10). The other potential roles of home gardens beyond the economy of rural households (SDG 2, 3, 5, 6, 8, 11-13,15) are less addressed by the policies.

To increase the representation of home gardens in Vietnam's rural development and agricultural policies, and therefore narrow the gap among research, policy, and actions in home garden contributions to Vietnam's SDGs, we recommend (1) extending national policies that have main targets other than income generation into provincial-level policies and setting specific targets for home gardens to ensure that policy implementation and funding also prioritize home gardens, (2) mainstreaming the diverse potential benefits of home gardens beyond the economy of rural households to decision makers and other relevant stakeholders and encouraging the development of integrated home garden systems that can help generate diverse benefits in home gardens of rural, peri-urban, and urban areas, schools, army camps etc., (3) enriching future rural development and agriculture policies with diverse and feasible targets based on existing or new research evidence, and strengthening coordination among state departments for policy implementation and achievement of the targets.

The current study has insufficiently addressed, however, a possible interrelation among the six key benefits of home gardens due to limited evidence in the literature. Future studies need to investigate such interrelation and other important issues such as potential impacts of policies supporting the cultivation of commercial crops in home gardens on rural communities and environment.

The synthesis of policy review and recommendation from this study can provide inputs to the ongoing national review process of rural development and agricultural policies in Vietnam for the period up to 2030. The methodology and framework for the policy review are replicable for similar research in other developing countries.

Author Contributions: Conceptualization, R.M. and E.S.; methodology, T.T.L. and R.M.; software, R.M.; validation, T.T.L., R.M., N.D.T. and E.S.; formal analysis, R.M.; investigation, T.T.L., N.D.T. and R.M.; resources, T.T.L. and E.S.; data curation, T.T.L., N.D.T. and R.M.; writing-original draft preparation, R.M.; writing-review and editing, R.M., T.T.L., N.D.T. and E.S.; visualization, R.M.; supervision, R.M. and E.S.; project administration, T.T.L. and E.S.; funding acquisition, T.T.L. and E.S. All authors have read and agreed to the published version of the manuscript.

Funding: This research received no external funding. The APC was funded by the United States Agency for International Development (USAID) grant number TF069018.

Institutional Review Board Statement: Not applicable.

Informed Consent Statement: Informed consent was obtained from all subjects involved in the study. 
Data Availability Statement: The data presented in this study are available on request from the corresponding author.

Acknowledgments: We sincerely thank Vu Thi Mai, To Nu Ngoc Anh, and Le Thi Hong Hanh for their help in reviewing the policies. We are also grateful for Hanna North for her valuable feedback to the content of the paper.

Conflicts of Interest: The authors declare no conflict of interest.

\section{Appendix A}

Table A1. Potential contributions of home gardens in Vietnam to Vietnam's sustainable development goals (source: World Agroforestry, data unpublished).

\begin{tabular}{|c|c|c|c|}
\hline $\begin{array}{c}\text { Vietnam's Relevant SDGs and } \\
\text { Targets * }\end{array}$ & $\begin{array}{l}\text { Link to Global } \\
\text { SDGs }\end{array}$ & Potential Contribution from Home Gardens & $\begin{array}{l}\text { Evidence from } \\
\text { Vietnam ** }\end{array}$ \\
\hline \multicolumn{4}{|c|}{ Goal 1: End all forms of poverty everywhere } \\
\hline $\begin{array}{l}\text { Target } 1.1 \text { Reducing the poverty rate } \\
\text { especially of vulnerable groups, } \\
\text { ethnic minorities, people with } \\
\text { disabilities, and women and children }\end{array}$ & Target 1.1 and 1.2 & $\begin{array}{l}\text { Generate short- and long-term income through } \\
\text { integrating annual and perennial crops, livestock } \\
\text { etc., and reduce cost of providing food for family. } \\
\text { Home gardens are also practiced by ethnic } \\
\text { minority communities in mountainous areas to } \\
\text { generate additional income }\end{array}$ & {$[8,35-40,85]$} \\
\hline $\begin{array}{l}\text { Target } 1.3 \text { Ensuring all citizens, } \\
\text { particularly the poor and the } \\
\text { vulnerable, have equal right to use } \\
\text { and own land }\end{array}$ & Target 1.4 & $\begin{array}{l}\text { Farmers usually have full power to decide } \\
\text { cultivation type and species selection for home } \\
\text { gardens. Home gardens are part of homesteads, } \\
\text { and rural households in Vietnam generally hold } \\
\text { a residential certificate }\end{array}$ & [8] \\
\hline $\begin{array}{l}\text { Target } 1.4 \text { Increase resilience of poor } \\
\text { and vulnerable groups to extreme } \\
\text { weather events, economic, social, } \\
\text { environmental shocks, and disasters }\end{array}$ & Target 1.5 & $\begin{array}{l}\text { Integrated agricultural practices in home } \\
\text { gardens can provide shade and windbreaks, } \\
\text { modify micro-climates, maintain soil humidity, } \\
\text { and reduce erosion, solar radiation, } \\
\text { and windspeed }\end{array}$ & {$[35,36,38,39]$} \\
\hline
\end{tabular}

Goal 2: Eliminate hunger, ensure food security, improve nutrition, and promote sustainable agricultural development

Target 2.1 Eliminate hunger and ensure access, by especially poor and vulnerable groups, to safe, nutritious, and sufficient food throughout the year

Target 2.2 Eliminate malnutrition and ensure fulfillment of nutritional needs for children, pregnant women, lactatingmothers and elderly people

Target 2.4 Ensure sustainable food production, apply resilient agricultural production modalities that also help maintain ecosystems, and improve land and soil quality

Target 2.5 Maintain and improve access to genetic diversity of plants and animals
Home gardens can produce diverse products such as rice, taros, fruits, vegetables, spices, Target 2.1 stimulants such as tea (Camellia sinensis), and fish and livestock as a source of protein for families throughout the year
$[8,35-39]$

Home gardens can produce fruits, vegetables,

Target 2.2 spices, stimulants, and protein from fish and

$[8,35-39]$ livestock to fulfill nutritional needs
Target 2.4

Perennial crops in home gardens can supply organic materials to the soil and reduce soil erosion and loss; nitrogen fixing trees can help maintain soil fertility; livestock waste can be used as manure

Home gardens can accommodate rich agrobiodiversity, including animals, as in situ Target 2.5 conservation and enable community members to access information on the genetic diversity and transmit the knowledge to younger generations

Goal 3: Ensure a healthy life and enhance welfare for all citizens of all age groups

Target 3.1 Reduce maternal and child mortality rate
Home gardens can produce nutritious foods and

Target 3.1 and 3.2 medicinal plants, and generate income to help reduce the maternal and child mortality rates
$[8,9,35,36]$ 
Table A1. Cont.

\begin{tabular}{lcl}
\hline $\begin{array}{c}\text { Vietnam's Relevant SDGs and } \\
\text { Targets * }\end{array}$ & $\begin{array}{c}\text { Link to Global } \\
\text { SDGs }\end{array}$ & Potential Contribution from Home Gardens \\
\hline \multicolumn{1}{c}{ Goal 5: Achieve gender equality; empower and create enabling opportunities for women and girls } \\
\hline $\begin{array}{l}\text { Target 5.1 End all forms of } \\
\text { discrimination towards women } \\
\text { and girls }\end{array}$ & Target 5.1 & $\begin{array}{l}\text { Women usually manage crops in home gardens } \\
\text { for food and nutrient security. This helps uplift } \\
\text { the status of women in their families }\end{array}$ \\
\hline $\begin{array}{l}\text { Target 5.4 Ensure gender equality in } \\
\text { domestic work and family care }\end{array}$ & Target 5.4 & $\begin{array}{l}\text { Thanks to crop diversification generating } \\
\text { different benefits, the tasks of maintaining and } \\
\text { managing home gardens are often shared } \\
\text { between men and women }\end{array}$ \\
\hline $\begin{array}{l}\text { Target 5.7 Ensure that all women can } \\
\text { access economic and natural } \\
\text { resources and can use and own land }\end{array}$ & Target 5a & $\begin{array}{l}\text { Thanks to their role in managing crops in home } \\
\text { gardens, at least those for food and nutrient } \\
\text { security, women can access natural resources } \\
\text { and can use land }\end{array}$ \\
\hline
\end{tabular}

Goal 6: Ensure the full supply of and sustainably manage water resources and hygienic systems for all citizens

Goal 6: Ensure the full supply of and sustainably manage water resources and hygienic systems for all citizens
\[ \begin{array}{l}\text { Fishponds in home gardens can provide water } \\ \text { for different purposes including irrigation, } \\ \text { animal consumption, and household needs; } \\ \text { integrated home garden systems can also } \\ \text { provide shade, modify micro-climates, and with } \\ \begin{array}{l}\text { Target } 6.4 \text { Increase water use } \\ \text { efficiency and reduce incidence of } \\ \text { water scarcity }\end{array} \\ \text { maintain soil humidity }\end{array} \]

Goal 8: Ensure sustainable, inclusive, and sustained economic growth, and generate full, productive employment and decent work for all citizens

Target 8.5 Achieve full and productive employment and decent work for all men and women
Home gardens can become the main source of family income that requires full engagement of men and women for maintenance and management
Target 8.5

Sustainable tourism and the associated culinary and handicraft sectors can use local products from home gardens. Tourism can also portray

Target 8.9 Develop sustainable tourism that promotes local cultures and products
Target 8.9

\section{local culture that uses products from home} gardens such as betel nut (Areca catechu) for wedding ceremonies and daily offerings to shrines

Goal 10: Reduce social inequalities

\begin{tabular}{lll}
$\begin{array}{l}\text { Target 10.1 Sustain income growth of } \\
\text { the poorest population }\end{array}$ & Target 10.1 & $\begin{array}{l}\text { Home garden is often practiced by ethnic } \\
\text { minorities in mountainous areas of Vietnam for } \\
\text { generating additional income and other benefits }\end{array}$ \\
\hline $\begin{array}{l}\text { Target 10.2 Promote political, } \\
\text { economic, and social inclusion of } \\
\text { all citizens }\end{array}$ & Target 10.2 & $\begin{array}{l}\text { Most rural households in Vietnam including } \\
\text { ethnic minorities have home gardens that can be } \\
\text { improved towards generating diverse economic } \\
\text { and social benefits }\end{array}$ \\
\hline
\end{tabular}

Goal 11: Promote sustainable, resilient urban and rural development; ensure safe living and working environments; ensure reasonable distribution of population and work force by region

Target 11.5 Reduce the number of deaths, people affected, and economic loss caused by natural and other disasters
Integrated home garden systems can help protect households and their homes from strong winds, Target $11.5 \quad$ can reduce the risk of severe soil erosion and loss in sloping lands, and modify micro-climates to reduce the impact of e.g., drought and heat 
Table A1. Cont.

\begin{tabular}{|c|c|c|c|}
\hline $\begin{array}{c}\text { Vietnam's Relevant SDGs and } \\
\text { Targets * }\end{array}$ & $\begin{array}{l}\text { Link to Global } \\
\text { SDGs }\end{array}$ & Potential Contribution from Home Gardens & $\begin{array}{l}\text { Evidence from } \\
\text { Vietnam ** }\end{array}$ \\
\hline $\begin{array}{l}\text { Target } 11.10 \text { Develop sustainable } \\
\text { rural areas that ensure harmony } \\
\text { between economy and } \\
\text { environmental protection }\end{array}$ & $\begin{array}{l}\text { Additional target } \\
\text { in Vietnam's SDG }\end{array}$ & $\begin{array}{l}\text { Home gardens can simultaneously generate } \\
\text { economic and ecological benefits to include } \\
\text { higher carbon sequestration for greenhouse gas } \\
\text { removal that results in lower net emission from } \\
\text { the systems }\end{array}$ & {$[5,9,36,40]$} \\
\hline
\end{tabular}

Goal 12: Ensure sustainable production and consumption

Target 12.3 Reduce post-harvest loss and food loss along production and supply chains

Risks of post-harvest and food losses are

Target 12.3

within homesteads

Goal 13: Respond in a timely and effective manner to climate change and natural disasters

Target 13.1 Strengthen resilience and adaptive capacity to climate-related hazards and capacity in responding Target $13.1 \quad$ Similar to Target 1.4 and 11.5

$[36,38,39]$ to natural and other disasters

Goal 15: Protect and sustainably develop forests; conserve biodiversity; develop eco-system services; combat desertification; prevent the degradation of and rehabilitate land resources

\begin{tabular}{lll}
$\begin{array}{l}\text { Target 15.2 Reduce deforestation and } \\
\text { strengthen the implementation of } \\
\text { sustainable forest management }\end{array}$ & Target 15.2 & $\begin{array}{l}\text { Home gardens can provide timber and } \\
\text { non-timber forest products including firewood } \\
\text { to reduce pressure on surrounding forests }\end{array}$ \\
\hline $\begin{array}{l}\text { Target 15.4 Conserve forest's } \\
\text { biodiversity and ecosystem services } \\
\text { for sustainable development }\end{array}$ & Target 15.4 & $\begin{array}{l}\text { Similar to Target 15.2, home gardens can also } \\
\text { become buffers for natural reserves }\end{array}$ \\
\hline $\begin{array}{l}\text { Target 15.5 Prevent the extinction of } \\
\text { endangered plant and animal species }\end{array}$ & Target 15.5 & $\begin{array}{l}\text { Home gardens can be used as in situ } \\
\text { conservation of plant species, including native } \\
\text { and endangered forest tree species }\end{array}$ \\
\hline & $\begin{array}{l}\text { * Detailed descriptions of the targets can be found in [43]. ** Based on a literature review with Web of Science and } \\
\text { Google Scholar using 'garden', 'home garden', 'home yard', or 'kitchen garden', and 'Vietnam' as search terms } \\
\text { (both in English and Vietnamese), for peer-reviewed journal articles and grey literature (book chapters, theses, } \\
\text { project reports, and working papers). Information from other types of publication such as news articles, blogs, or } \\
\text { presentations were excluded. }\end{array}$
\end{tabular}

Table A2. The 25 home garden policies enacted over the last decade (2010-2021).

\begin{tabular}{|c|c|c|c|c|}
\hline No * & Policy Title in Vietnamese & Policy Title in English & Policy Number & Issued Date $(\mathrm{d} / \mathrm{m} / \mathrm{y})$ \\
\hline 1 & $\begin{array}{l}\text { Quyết định ban hành bộ tiêu chí } \\
\text { xây dựng vườn mẫu nông thôn mới } \\
\text { áp dụng trên địa bàn tỉnh Hà Tĩnh }\end{array}$ & $\begin{array}{l}\text { Decision on criteria for developing } \\
\text { new home garden demonstration } \\
\text { models for Ha Tinh province }\end{array}$ & $\begin{array}{c}\text { QĐ 59/2015/QĐ- } \\
\text { UBND }\end{array}$ & 24 November 2015 \\
\hline 2 & $\begin{array}{l}\text { Quyết định ban hành định mức hỗ } \\
\text { trợ phát triển sản xuất giai đoạn } \\
\text { 2016-2020 chương trình mục tiêu } \\
\text { quốc gia xây dựng nông thôn mới } \\
\text { trên địa bàn tỉnh Bình Định }\end{array}$ & $\begin{array}{l}\text { Decision promulgating norms to } \\
\text { support agricultural production for } \\
\text { the period of } 2016-2020 \text { and the } \\
\text { national target program on } \\
\text { building new rural areas in Binh } \\
\text { Dinh province }\end{array}$ & $\begin{array}{c}\text { QĐ 67/2016/QĐ- } \\
\text { UBND }\end{array}$ & 15 December 2016 \\
\hline 3 & $\begin{array}{l}\text { Quyết định 849/QĐ-UBND năm } \\
2017 \text { về Bộ tiêu chí tạm thời xây } \\
\text { dựng vườn mẫu nông thôn mới áp } \\
\text { dụng trên địa bàn các thôn thuộc } \\
\text { tịnh Quảng Ninh }\end{array}$ & $\begin{array}{l}\text { Decision on temporary indicators } \\
\text { for new rural development and } \\
\text { home garden demonstration } \\
\text { models in Quang Ninh province }\end{array}$ & $\begin{array}{c}\text { QĐ 849/2017/QĐ- } \\
\text { UBND }\end{array}$ & 17 March 2017 \\
\hline
\end{tabular}


Table A2. Cont.

\begin{tabular}{|c|c|c|c|c|}
\hline No * & Policy Title in Vietnamese & Policy Title in English & Policy Number & Issued Date $(\mathrm{d} / \mathrm{m} / \mathrm{y})$ \\
\hline 4 & $\begin{array}{l}\text { Quyết định quy định bộ tiêu chí } \\
\text { thôn nông thôn mới kiểu mẫu và } \\
\text { thẩm quyền xét, công nhận, công } \\
\text { bố thôn nông thôn mới kiểu mẫu } \\
\text { trên địa bàn tỉnh Bắc Giang }\end{array}$ & $\begin{array}{l}\text { Decision stipulating a set of criteria } \\
\text { for modeling new rural areas and } \\
\text { competence to consider, recognize, } \\
\text { and announce the model of new } \\
\text { rural areas for Bac Giang province }\end{array}$ & $\begin{array}{c}\text { QĐ 11/2018/QĐ- } \\
\text { UBND }\end{array}$ & 15 May 2018 \\
\hline 5 & $\begin{array}{l}\text { Quyết định về việc ban hành tiêu } \\
\text { chí, điều kiện, trình tự, thủ tục, hồ } \\
\text { sơ xét, công nhận và công bố xã đạt } \\
\text { chuẩn nông thôn mới nâng cao trên } \\
\text { địa bàn tỉnh Thanh Hóa, giai đoạn } \\
\text { 2018-2020 }\end{array}$ & $\begin{array}{l}\text { Decision promulgating criteria, } \\
\text { conditions, order, procedures, } \\
\text { dossiers for consideration, } \\
\text { recognition and announcement of } \\
\text { communes meeting the new and } \\
\text { improved rural standards for } \\
\text { Thanh Hoa province from } \\
\text { 2018-2020 }\end{array}$ & $\begin{array}{c}\text { QĐ 25/2018/QĐ- } \\
\text { UBND }\end{array}$ & 10 August 2018 \\
\hline
\end{tabular}

Quyết định 1799/QĐ-UBND năm mẫu trên địa bàn tỉnh Thừa Thiên Huê' giai đoạn 2018-2020
Decision on criteria for building home garden demonstration models in Thua Thien Hue province for the period of 2018-2020
62018 về Bộ tiêu chí xây dựng vườn

QĐ 1799/2018/QĐUBND

14 August 2018 Decision promulgating the criteria for new rural village models for Kon Tum province for the period of 2018-2020

Quyết định ban hành bộ tiêu chí về

7 khu dân cư nông thôn mới kiểu mẫu giai đoạn 2018-2020 trên địa bàn tỉnh Kon Tum

Quyết định về việc ban hành bộ tiêu chí vườn mẫu-rẫy mẫu trong xây dựng nông thôn mới trên địa bàn tỉnh Dắk Nông

Quyết định về Bộ tiêu chí Khu dân cư nông thôn mới kiểu mẫu và vườn mẫu tỉnh Hòa Bình giai đoạn 2018-2020

Quyết định ban hành điều kiện, tiêu chí xã đạt chuẩn nông thôn mới nâng cao, thôn dân cư nông thôn mới kiểu mẫu, điều kiện xã nông thôn mới kiểu mẫu tỉnh Vĩnh Phúc giai đoạn 2019-2020

Decision on criteria for developing new home garden demonstration models for Dak Nong province

QĐ 1467/2018/QĐUBND

18 September 2018

Decision on indicators for new rural development and home garden demonstration models in Hoa Binh province for the period of QĐ 188/2018/QĐUBND

20 September 2018 2018-2020

Decision promulgating conditions and criteria for new and improved models of rural communes, new models of rural demonstration villages, and new rural communes

QĐ 08/2019/QĐUBND

14 February 2019 in Vinh Phuc province for the period of 2019-2020

Decision promulgating the criteria of new model of rural villages and demonstration model of agricultural production for Ben Tre

QĐ 373/2019/QĐUBND

1 March 2019 province from 2019-2020

Decision on indicators of new rural development and home garden demonstration models for Tuyen Quang province until 2020

12 tiêu chí vườn mẫu nông thôn mới trên địa bàn tỉnh Tuyên Quang, đến năm 2020

Quyết định ban hành quy định bộ

13 tiêu chí khu dân cư nông thôn mới kiểu mẫu, vườn mẫu nông thôn mới trên địa bàn tỉnh Phú Yên

Decision promulgating the criteria of new models of rural village and home garden demonstration models for Phu Yen province

Kế hoạch xây dựng khu dân cư

14 nông thôn mới kiểu mẫu năm 2019 trên địa bàn tỉnh Kon Tum
Plan to build a new model of rural areas in 2019 for Kon Tum province
KH 892/2019/KHUBND
12 September 2018

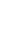


Table A2. Cont.

\begin{tabular}{|c|c|c|c|c|}
\hline No * & Policy Title in Vietnamese & Policy Title in English & Policy Number & Issued Date $(\mathrm{d} / \mathrm{m} / \mathrm{y})$ \\
\hline 15 & $\begin{array}{l}\text { Quyết định ban hành kế hoạch xây } \\
\text { dựng và hỗ trợ khu dân cư nông } \\
\text { thôn kiểu mẫu trên địa bàn tỉnh } \\
\text { Quảng Ngãi, giai đoạn 2019-2020. }\end{array}$ & $\begin{array}{l}\text { Decision promulgating the plan } \\
\text { and support for building new } \\
\text { models of rural villages for Quang } \\
\text { Tri province from 2018-2021 }\end{array}$ & $\begin{array}{l}\text { QĐ 602/2019/QĐ- } \\
\text { UBND }\end{array}$ & 3 May 2019 \\
\hline 16 & $\begin{array}{l}\text { Quyết định 1606/QĐ-UBND năm } \\
2019 \text { về Bộ Tiêu chí khu dân cư } \\
\text { nông thôn mới kiểu mẫu, vườn } \\
\text { mẫu nông thôn mới giai đoạn } \\
\text { 2019-2020 trên địa bàn tỉnh } \\
\text { Bình Định }\end{array}$ & $\begin{array}{l}\text { Decision issuing indicators for new } \\
\text { rural development and home } \\
\text { garden demonstration models for } \\
\text { Binh Dinh province for the period } \\
\text { of } 2019-2020\end{array}$ & $\begin{array}{c}\text { QĐ 1606/2019/QĐ- } \\
\text { UBND }\end{array}$ & 14 May 2019 \\
\hline 17 & $\begin{array}{l}\text { Kế hoạch thực hiện xây dựng khu } \\
\text { dân cư nông thôn mới kiểu mẫu, } \\
\text { vườn mẫu nông thôn mới trên địa } \\
\text { bàn tỉnh Phú Yên }\end{array}$ & $\begin{array}{l}\text { Plan to build a new rural } \\
\text { development and home garden } \\
\text { demonstration model for Phu } \\
\text { Yen province }\end{array}$ & $\begin{array}{c}\text { KH } 120 / 2019 / K H- \\
\text { UBND }\end{array}$ & 27 May 2019 \\
\hline 18 & $\begin{array}{l}\text { Quyết định 1333/QĐ-UBND năm } \\
2019 \text { về Bộ tiêu chí “Bản nông thôn } \\
\text { mới”, "Bản nông thôn mới kiểu } \\
\text { mẫu”, "Bản nông thôn mới của các } \\
\text { xã đặc biệt khó khăn khu vực biên } \\
\text { giới” tỉnh Sơn La, giai đoạn } \\
\text { 2019-2020 }\end{array}$ & $\begin{array}{l}\text { Decision promulgating indicators } \\
\text { of "new rural village", "new model } \\
\text { of rural village", "new rural village } \\
\text { of extremely difficult communes in } \\
\text { the border areas" of Son La } \\
\text { province, for the period of } \\
2019-2020\end{array}$ & $\begin{array}{c}\text { QĐ } 1333 / 2019 / Q Đ- \\
\text { UBND }\end{array}$ & 12 June 2019 \\
\hline 19 & $\begin{array}{l}\text { Quyết định ban hành bộ tiêu chí } \\
\text { thôn, bản nông thôn mới kiểu mẫu } \\
\text { trên địa bàn tỉnh Quảng Trị giai } \\
\text { đoạn 2019-2020 }\end{array}$ & $\begin{array}{l}\text { Decision promulgating the criteria } \\
\text { of new models of rural villages for } \\
\text { Quang Tri province from 2019-2020 }\end{array}$ & $\begin{array}{c}\text { QĐ } 1647 / 2019 / Q Đ- \\
\text { UBND }\end{array}$ & 2 July 2019 \\
\hline 20 & $\begin{array}{l}\text { Quyết định về Bộ tiêu chí thôn } \\
\text { nông thôn mới kiểu mẫu trên địa } \\
\text { bàn thành phố Đà Nắng, giai đoạn } \\
\text { 2019-2020 }\end{array}$ & $\begin{array}{l}\text { Decision promulgating the criteria } \\
\text { of new models of rural villages for } \\
\text { Da Nang city from 2019-2020 }\end{array}$ & $\begin{array}{c}\text { QĐ 3565/2019/QĐ- } \\
\text { UBND }\end{array}$ & 12 August 2019 \\
\hline 21 & $\begin{array}{l}\text { Quyết định về Sổ tay hướng dẫn } \\
\text { thực hiện Bộ tiêu chí xã nông thôn } \\
\text { mới nâng cao tỉnh Bình Dương }\end{array}$ & $\begin{array}{l}\text { Decision on guideline of indicators } \\
\text { for new rural communes in Binh } \\
\text { Duong province }\end{array}$ & $\begin{array}{c}\text { QĐ 2575/2019/QĐ- } \\
\text { UBND }\end{array}$ & 9 September 2019 \\
\hline 22 & $\begin{array}{l}\text { Quyết định về tiêu chí xã nông } \\
\text { thôn mới kiểu mẫu trên địa bàn } \\
\text { tỉnh Lâm Đồng giai đoạn 2019-2020 }\end{array}$ & $\begin{array}{l}\text { Decision promulgating the criteria } \\
\text { of new models of rural communes } \\
\text { for Lam Dong province, for the } \\
\text { period of 2019-2020 }\end{array}$ & $\begin{array}{c}\text { QĐ 2584/2019/QĐ- } \\
\text { UBND }\end{array}$ & 11 December 2019 \\
\hline 23 & $\begin{array}{l}\text { Quyết định về Bộ tiêu chí khu dân } \\
\text { cư nông thôn mới kiểu mẫu trên địa } \\
\text { bàn tỉnh Bình Thuận đến năm } 2020\end{array}$ & $\begin{array}{l}\text { Decision on indicators for new } \\
\text { models of rural areas in Binh Thuan } \\
\text { province until } 2020\end{array}$ & $\begin{array}{l}\text { QĐ 192/2020/QĐ- } \\
\text { UBND }\end{array}$ & 21 January 2020 \\
\hline 24 & $\begin{array}{l}\text { Quyết định về việc ban hành bộ } \\
\text { tiêu chí âp nông thôn mới kiểu } \\
\text { mẫu, vườn mẫu giai đoạn } \\
\text { 2019-2020 tỉnh Kiên Giang }\end{array}$ & $\begin{array}{l}\text { Decision promulgating criteria for } \\
\text { new rural development and home } \\
\text { garden demonstration models in } \\
\text { Kien Giang province for the period } \\
\text { of } 2019-2020\end{array}$ & $\begin{array}{l}\text { QĐ 210/2020/QĐ- } \\
\text { UBND }\end{array}$ & 21 January 2020 \\
\hline 25 & $\begin{array}{l}\text { Quyết định 1211/QĐ-UBND năm } \\
2020 \text { quy định về điều kiện, trình } \\
\text { tự, thư tục, hồ sơ xét, công nhận và } \\
\text { công bố khu dân cư nông thôn mới } \\
\text { kiểu mẫu; vườn mẫu nông thôn } \\
\text { mới trên địa bàn tỉnh Quảng Bình }\end{array}$ & $\begin{array}{l}\text { Decision on conditions, order, } \\
\text { procedures, dossiers for review, } \\
\text { recognition, and announcement of } \\
\text { new models of rural areas; home } \\
\text { garden demonstration models in } \\
\text { Quang Binh province }\end{array}$ & $\begin{array}{l}\text { QĐ } 1211 / 2020 / Q Đ-~ \\
\text { UBND }\end{array}$ & 22 April 2020 \\
\hline
\end{tabular}


Table A3. Income indicators used in the home garden policies.

\begin{tabular}{|c|c|c|c|c|c|}
\hline \multirow[b]{2}{*}{ No * } & \multirow[b]{2}{*}{ Policy Number } & \multicolumn{4}{|c|}{ Income Indicators } \\
\hline & & $\begin{array}{l}\text { Income } \\
\text { Relative to } \\
\text { Paddy Rice }\end{array}$ & Annual Income by Land Size & $\begin{array}{l}\text { Income Share from } \\
\text { Main Product to } \\
\text { Total Income }\end{array}$ & Income per Capita \\
\hline 1 & $\begin{array}{c}\text { QĐ } \\
\text { 59/2015/QĐ-UBND }\end{array}$ & & $\begin{array}{l}\geq \text { USD } 2608 \text { for land size } \\
\leq 1000 \mathrm{~m}^{2}, \geq \text { USD } 3478 \text { for } \\
>1000-2000 \mathrm{~m}^{2}, \geq \text { USD } 5217 \\
\text { for }>2000-3000 \mathrm{~m}^{2}, \text { USD } 6251 \\
\text { for } \geq 3000 \mathrm{~m}^{2}\end{array}$ & $\geq 75 \%$ & \\
\hline 2 & $\begin{array}{c}\text { QĐ } \\
67 / 2016 / Q Đ-U B N D\end{array}$ & \multicolumn{4}{|c|}{ No indicator is provided } \\
\hline 3 & $\begin{array}{c}\text { QĐ 849/2017/QĐ- } \\
\text { UBND }\end{array}$ & 5 times & $\begin{array}{c}\geq \text { USD } 1739 \text { for land size } \\
\leq 1000 \mathrm{~m}^{2}, \geq \text { USD } 2608 \text { for } \\
>1000-2000 \mathrm{~m}^{2}, \geq \text { USD } 3913 \\
\text { for }>2000-3000 \mathrm{~m}^{2}, \text { USD } 5652 \\
\text { for } \geq 3000 \mathrm{~m}^{2}\end{array}$ & $\geq 75 \%$ & \\
\hline 4 & $\begin{array}{c}\mathrm{QĐ} \\
11 / 2018 / \mathrm{Q} Đ-U B N D\end{array}$ & & & & $\begin{array}{l}\geq \text { USD } 4347, \leq 5 \% \\
\text { poverty rate based on } \\
\text { the multidimensional } \\
\text { criteria in } 2016-2020\end{array}$ \\
\hline 5 & $\begin{array}{c}\text { QĐ } \\
25 / 2018 / Q Đ-U B N D\end{array}$ & & & $\geq 75 \%$ & \\
\hline 6 & $\begin{array}{c}\text { QĐ } 1799 / 2018 / Q Đ- \\
\text { UBND }\end{array}$ & 5 times & & $\geq 51 \%$ & \\
\hline 7 & $\begin{array}{l}\text { QĐ 965/2018/QĐ- } \\
\text { UBND }\end{array}$ & & & $\geq 80 \%$ & \\
\hline 8 & $\begin{array}{c}\text { QĐ } 1467 / 2018 / \mathrm{Q} Đ- \\
\text { UBND }\end{array}$ & & $\begin{array}{c}\geq \text { USD } 2608 \text { for land size } \\
\leq 1000 \mathrm{~m}^{2}, \geq \text { USD } 3478 \text { for } \\
>1000-2000 \mathrm{~m}^{2}, \geq \text { USD } 5817 \\
\text { for }>2000-3000 \mathrm{~m}^{2}, \text { USD } 6521 \\
\text { for } \geq 3000 \mathrm{~m}^{2}\end{array}$ & $\geq 75 \%$ & \\
\hline 9 & $\begin{array}{l}\text { QĐ 188/2018/QĐ- } \\
\text { UBND }\end{array}$ & 3 times & $\begin{array}{l}\geq \text { USD } 2173 \text { for land size } \\
\leq 1000 \mathrm{~m}^{2}, \geq \text { USD } 3043 \text { for } \\
>1000-2000 \mathrm{~m}^{2}, \geq \text { USD } 4347 \\
\text { for }>2000-3000 \mathrm{~m}^{2}, \text { USD } 5217 \\
\text { for } \geq 3000 \mathrm{~m}^{2}\end{array}$ & & \\
\hline 10 & $\begin{array}{c}\text { QĐ } \\
\text { 08/2019/QĐ-UBND }\end{array}$ & & & $\geq 70 \%$ & $\begin{array}{l}1.2 \text { times higher than } \\
\text { that generated by the } \\
\text { commune that meets } \\
\text { the new } \\
\text { rural standards }\end{array}$ \\
\hline 11 & $\begin{array}{c}\text { QĐ 373/2019/QĐ- } \\
\text { UBND }\end{array}$ & & $\begin{array}{c}\geq \text { USD } 2608 \text { per } 1000 \mathrm{~m}^{2} \text { for } \\
\text { land size } \leq 1000 \mathrm{~m}^{2}, \geq \text { USD } \\
2173 \text { per } 1000 \mathrm{~m}^{2} \text { for } \\
>1000-2000 \mathrm{~m}^{2}, \geq \text { USD } 1739 \\
\text { per } 1000 \mathrm{~m}^{2} \text { for } \\
>2000-3000 \mathrm{~m}^{2}, \text { USD } 1304 \text { per } \\
1000 \mathrm{~m}^{2} \text { for } \geq 3000 \mathrm{~m}^{2}\end{array}$ & $\geq 50 \%$ & \\
\hline 12 & $\begin{array}{c}\text { QĐ } \\
\text { 73/2019/QĐ-UBND }\end{array}$ & 5 times & & & \\
\hline
\end{tabular}


Table A3. Cont.

\begin{tabular}{|c|c|c|c|c|c|}
\hline \multirow[b]{2}{*}{ No * } & \multirow[b]{2}{*}{ Policy Number } & \multicolumn{4}{|c|}{ Income Indicators } \\
\hline & & $\begin{array}{c}\text { Income } \\
\text { Relative to } \\
\text { Paddy Rice }\end{array}$ & Annual Income by Land Size & $\begin{array}{l}\text { Income Share from } \\
\text { Main Product to } \\
\text { Total Income }\end{array}$ & Income per Capita \\
\hline 13 & $\begin{array}{c}\text { QĐ } \\
\text { 05/2019/QĐ-UBND }\end{array}$ & 5 times & & $\geq 70 \%$ & \\
\hline 14 & $\begin{array}{c}\text { KH } 892 / 2019 / \mathrm{KH}- \\
\text { UBND }\end{array}$ & \multicolumn{4}{|c|}{ No indicator is provided } \\
\hline 15 & $\begin{array}{l}\text { QĐ 602/2019/QĐ- } \\
\text { UBND }\end{array}$ & \multicolumn{4}{|c|}{ No indicator is provided } \\
\hline 16 & $\begin{array}{l}\text { QĐ 1606/2019/QĐ- } \\
\text { UBND }\end{array}$ & & $\begin{array}{c}\geq \text { USD } 2608 \text { for land size } \\
\leq 1000 \mathrm{~m}^{2}, \geq \text { USD } 3478 \text { for } \\
>1000-2000 \mathrm{~m}^{2}, \geq \text { USD } 5217 \\
\text { for }>2000-3000 \mathrm{~m}^{2}, \text { USD } 6251 \\
\text { for } \geq 3000 \mathrm{~m}^{2}\end{array}$ & $\geq 75 \%$ & \\
\hline 17 & $\begin{array}{c}\text { KH } 120 / 2019 / \mathrm{KH}- \\
\text { UBND }\end{array}$ & \multicolumn{4}{|c|}{ No indicator is provided } \\
\hline 18 & $\begin{array}{l}\text { QĐ } 1333 / 2019 / Q Đ- \\
\text { UBND }\end{array}$ & & & & $\begin{array}{l}\geq 18.5 \text { million by } 2020 \\
\text { (1.6 times higher than } \\
\text { rural income in } 2015 \text { ) }\end{array}$ \\
\hline 19 & $\begin{array}{l}\text { QĐ 1647/2019/QĐ- } \\
\text { UBND }\end{array}$ & & & & $\begin{array}{l}\text { At least } 10 \% \text { higher } \\
\text { than that generated by } \\
\text { the commune that } \\
\text { meets the new } \\
\text { rural standards }\end{array}$ \\
\hline 20 & $\begin{array}{c}\text { QĐ 3565/2019/QĐ- } \\
\text { UBND }\end{array}$ & & & & $\begin{array}{l}\text { At least } 1.2 \text { times } \\
\text { higher than that } \\
\text { generated by the } \\
\text { commune that meets } \\
\text { the new } \\
\text { rural standards }\end{array}$ \\
\hline 21 & $\begin{array}{c}\text { QĐ } 2575 / 2019 / Q Đ- \\
\text { UBND }\end{array}$ & & & & $\begin{array}{l}\text { USD } 2391 \text { in } 2018, \\
\text { USD } 2608 \text { in } 2019, \\
\text { USD } 2826 \text { in } 2020\end{array}$ \\
\hline 22 & $\begin{array}{c}\text { QĐ 2584/2019/QĐ- } \\
\text { UBND }\end{array}$ & & & & $\begin{array}{l}\text { At least } 1.5 \text { times } \\
\text { higher than that } \\
\text { generated by the } \\
\text { commune that meets } \\
\text { the new } \\
\text { rural standards }\end{array}$ \\
\hline 23 & $\begin{array}{l}\text { QĐ 192/2020/QĐ- } \\
\text { UBND }\end{array}$ & & & & USD 2695 by 2020 \\
\hline 24 & $\begin{array}{l}\text { QĐ 210/2020/QĐ- } \\
\text { UBND }\end{array}$ & & $\geq$ USD 3043 per $1.000 \mathrm{~m}^{2}$ & & \\
\hline 25 & $\begin{array}{l}\text { QĐ 1211/2020/QĐ- } \\
\text { UBND }\end{array}$ & 5 times & & & \\
\hline
\end{tabular}

${ }^{*}$ Ordered based on date of issue. 
Table A4. Support mechanisms by the home garden policies.

\begin{tabular}{|c|c|c|}
\hline Mechanisms & Supported Species, Model, or Activity & Policies That Provide Supports \\
\hline \multicolumn{3}{|c|}{ 1. Farmers cultivate crop species or develop home garden models specified by the policies } \\
\hline \multicolumn{3}{|l|}{ 1.1 Crop species } \\
\hline $\begin{array}{l}\text { 1.1.1 Names explicitly } \\
\text { mentioned by the policies }\end{array}$ & $\begin{array}{l}\text { Tea, pomelo, and black pepper } \\
\text { (Piper nigrum) }\end{array}$ & 1 policy: QĐ 67/2016/QĐ-UBND \\
\hline $\begin{array}{l}\text { 1.1.2 Flagship commodities (no } \\
\text { species name is provided) }\end{array}$ & $\begin{array}{l}\text { For example, according to the other } \\
\text { reference (not the home garden policies) } \\
\text { e.g., Decision QĐ 46/2019/QĐ-UBND, the } \\
\text { flagship commodities of Ben Tre province } \\
\text { include coconut and fruit products such as } \\
\text { longan and mango }\end{array}$ & $\begin{array}{c}9 \text { policies: QĐ 849/2017/QĐ-UBND, QĐ } \\
\text { 25/2018/QĐ-UBND, QĐ 1799/2018/QĐ-UBND, } \\
\text { QĐ 1467/2018/QĐ-UBND, QĐ } \\
\text { 1333/2019/QĐ-UBND, QĐ } \\
\text { 2584/2019/QĐ-UBND, QĐ } \\
\text { 2575/2019/QĐ-UBND, QĐ 05/2019/QĐ-UBND, } \\
\text { QĐ 373/2019/QĐ-UBND }\end{array}$ \\
\hline 1.2 Home garden model & $\begin{array}{l}\text { Garden-pond-livestock pen (or } \\
\text { vườn-ao-chuồng in Vietnamese) }\end{array}$ & 1 policy: KH 892/2019/KH-UBND \\
\hline
\end{tabular}

2. Farmers can propose crop species, home garden model, or activity to improve production and product quality to the People's Committee

$\begin{array}{cc}\text { 2.1 Crop species } & \text { Any crop species but likely those that can } \\ \text { generate high income } & \text { 22 policies: all policies in Table A2 except QĐ } \\ & \text { 59/2015/QĐ-UBND, QĐ 67/2016/QĐ-UBND, } \\ \text { KH 892/2019/KH-UBND }\end{array}$

$\begin{array}{llc} & \text { The model must aim towards improving } & 23 \text { policies: all policies in Table A2 except QĐ } \\ \text { 2.2 Home garden model } & \begin{array}{c}\text { income or product quality and minimize } \\ \text { any negative impact on the environment }\end{array} & 892 / 2019 / \text { QH } \\ & \end{array}$

Improve product quality and obtain certification such as the Vietnam's Good Agricultural Practices (VietGAP)

1 policy: QĐ 2575/2019/QĐ-UBND 8 policies: QĐ 188/2018/QĐ-UBND, QĐ

Improve water storage or irrigation systems 25/2018/QĐ-UBND, QĐ 1799/2018/QĐ-UBND, QĐ 1467/2018/QĐ-UBND, QĐ 1606/2019/QĐ-UBND, QĐ 373/2019/QĐ-UBND, QĐ 1211/2020/QĐ-UBND, QĐ 2.3 Activities to improve production and product quality 210/2020/QĐ-UBND

16 policies: QĐ 849/2017/QĐ-UBND, QĐ
188/2018/QĐ-UBND, QĐ 25/2018/QĐ-UBND,
QĐ 1799/2018/QĐ-UBND, QĐ
1467/2018/QĐ-UBND, QĐ
965/2018/QĐ-UBND, QĐ
1333/2019/QĐ-UBND, QĐ 73/2019/QĐ-UBND,
QĐ 1606/2019/QĐ-UBND, QĐ
2584/2019/QĐ-UBND, QĐ
2575/2019/QĐ-UBND, QĐ 05/2019/QĐ-UBND,
QĐ 373/2019/QĐ-UBND, QĐ
1211/2020/QĐ-UBND, QĐ
192/2020/QĐ-UBND, QĐ 210/2020/QĐ-UBND

\section{References}

1. Shubha, K.; Mukherjee, A.; Anand, S.; Koley, T.K.; Kumar, U. Nutri-garden for achieving Sustainable Development Goals (SDGs). Food Sci. Rep. 2020, 1, 25-27.

2. Mondal, P.; DeFries, R.; Clark, J.; Flowerhill, N.; Arif, M.; Harou, A.; Downs, S.; Fanzo, J. Multiple cropping alone does not improve year-round food security among smallholders in rural India. Environ. Res. Lett. 2021, 16, 065017. [CrossRef]

3. Lunderstedt, K.; Gambiza, J.; Kahinda, J.-M. Home Garden Agroforestry and Conservation Agriculture Promotes Food Security in Rural South Africa. Available online: https:/ / www.za.undp.org/content/south_africa/en/home/presscenter/articles/2020 /home-garden-agroforestry-.html (accessed on 19 January 2022). 
4. Galhena, D.H.; Freed, R.; Maredia, K.M. Home gardens: A promising approach to enhance household food security and wellbeing. Agric. Food Secur. 2013, 2, 8. [CrossRef]

5. Mohri, H.; Lahoti, S.; Saito, O.; Mahalingam, A.; Gunatilleke, N.; Irham; Hoang, V.T.; Hitinayake, G.; Takeuchi, K.; Herath, S. Assessment of ecosystem services in homegarden systems in Indonesia, Sri Lanka, and Vietnam. Ecosyst. Serv. 2013, 5, 124-136. [CrossRef]

6. Gautam, R.; Sthapit, B.; Subedi, A.; Poudel, D.; Shrestha, P.; Eyzaguirre, P. Home gardens management of key species in Nepal: A way to maximize the use of useful diversity for the well-being of poor farmers. Plant Genet. Resour. 2009, 7, 142-153. [CrossRef]

7. Abdoellah, O.S.; Schneider, M.; Nugraha, L.M.; Suparman, Y.; Voletta, C.T.; Withaningsih, S.; Parikesit; Heptiyanggit, A.; Hakim, L. Homegarden commercialization: Extent, household characteristics, and effect on food security and food sovereignty in Rural Indonesia. Sustain. Sci. 2020, 15, 797-815. [CrossRef]

8. Trinh, L.N.; Watson, J.W.; Hue, N.N.; De, N.N.; Minh, N.V.; Chu, P.; Sthapit, B.R.; Eyzaguirre, P.B. Agrobiodiversity conservation and development in Vietnamese home gardens. Agric. Ecosyst. Environ. 2003, 97, 317-344. [CrossRef]

9. Vlkova, M.; Polesny, Z.; Verner, V.; Banout, J.; Dvorak, M.; Havlik, J.; Lojka, B.; Ehl, P.; Krausova, J. Ethnobotanical knowledge and agrobiodiversity in subsistence farming: Case study of home gardens in Phong My commune, central Vietnam. Genet. Resour. Crop Evol. 2011, 58, 629-644. [CrossRef]

10. Watson, J.W.; Eyzaguirre, P.B. Contribution of home gardens to in situ conservation of plant genetic resources in farming systems In Proceedings of the Second International Home Gardens Workshop, Witzenhausen, Germany, 17-19 July 2001; International Plant Genetic Resources Institute: Rome, Italy, 2002; p. 184.

11. Food System Summit 2021 Game Changing Propositions. Available online: https:/ / foodsystems.community / game-changingpropositions / (accessed on 12 December 2021).

12. Seneviratne, G.; Kuruppuarachchi, K.A.J.M.; Somaratne, S.; Seneviratne, K.A.C.N. Nutrient cycling and safety-net mechanism in the tropical homegardens. Int. J. Agric. Res. 2006, 1, 169-182. [CrossRef]

13. Kehlenbeck, K. Rural Homegardens in Central Sulawesi, Indonesia: An Example for a Sustainable Agro-Ecosystem? Ph.D. Thesis, Georg-August-Universität Göttingen, Göttingen, Germany, 2007.

14. Gautam, R.; Sthapit, B.R.; Shrestha, P.K. Home gardens in Nepal. In Enhancing the Contribution of Home Garden to On-Farm Management of Plant Genetic Resources and to Improve the Livelihoods of Nepalese Farmers: Lessons Learned and Policy Implications; Gautam, R., Sthapit, B.R., Shrestha, P.K., Eds.; LI-BIRD, Bioversity International and SDC: Pokhara, Nepal, 2004.

15. Okigbo, B. Home gardens in tropical Africa. In Tropical Home Gardens; Landauer, K., Brazil, M., Eds.; United Nations University Press: Tokyo, Japan, 1990.

16. Mitchell, R.; Hanstad, T. Small Homegarden Plots and Sustainable Livelihoods for the Poor; Food and Agricultural Organization of the United Nations: Rome, Italy, 2004.

17. Patalagsa, M.A.; Schreinemachers, P.; Begum, S.; Begum, S. Sowing seeds of empowerment: Effect of women's home garden training in Bangladesh. Agric. Food Secur. 2015, 4, 24. [CrossRef]

18. Hillenbrand, E. Transforming gender in homestead food production. Gend. Dev. 2010, 18, 411-425. [CrossRef]

19. Jacob, V.J.; Alles, W.S. Kandyan gardens of Sri Lanka. Agrofor. Syst. 1987, 5, 123-137. [CrossRef]

20. Christanty, L.; Abdoellah, O.L.; Marten, G.G.; Iskandar, J. Traditional agroforestry in West Java: The pekarangan (home garden) and kebun-talun (annual perennial rotation) cropping systems. In Traditional Agriculture in South East Asia; Marten, G., Ed.; Westview Press: Boulder, CO, USA, 1986.

21. Howard, P.L. Gender and social dynamics in swidden and homegardens in Latin America. In Tropical Homegardens: A Time-Tested Example of Sustainable Agroforestry; Nair, B., Ed.; Springer Science: Dodrecht, The Netherlands, 2006.

22. Roshetko, J.M.; Delaney, M.; Hairiah, K.; Purnomosidhi, P. Carbon stocks in Indonesian homegarden systems: Can smallholder systems be targeted for increased carbon storage? Am. J. Altern. Agric. 2002, 17, 138-148. [CrossRef]

23. Feliciano, D.; Ledo, A.; Hillier, J.; Nayak, D.R. Which agroforestry options give the greatest soil and above ground carbon benefits in different world regions? Agric. Ecosyst. Environ. 2018, 254, 117-129. [CrossRef]

24. Agbogidi, O.M.; Adolor, E.B. Home gardens in the maintenance of biological diversity. J. Adv. Biol. 2013, 2, 127-134.

25. Albuquerque, U.P.; Andrade, L.H.C.; Caballero, J. Structure and floristics of homegardens in Northeastern Brazil. J. Arid Environ. 2005, 62, 491-506. [CrossRef]

26. Blanckaert, I.; Swennen, R.; Paredes Flores, M.; Rosas López, R.; Lira Saade, R. Floristic composition, plant uses and management practices in homegardens of San Rafael Coxcatlán, Valley of Tehuacán-Cuicatlán, Mexico. J. Arid Environ. 2004, 57, 179-202. [CrossRef]

27. Mattsson, E.; Ostwald, M.; Nissanka, S.P.; Marambe, B. Homegardens as a multi-functional land-use strategy in Sri Lanka with focus on carbon sequestration. Ambio 2013, 42, 892-902. [CrossRef]

28. Engels, J.; Watson, J.; Eyzaguirre, P. Home gardens-A genetic resources perspective. In Proceedings of the Second International Home Gardens Workshop, Witzenhausen, Germany, 17-19 July 2001; International Plant Genetic Resources Institute: Rome, Italy, 2002.

29. Mulia, R.; Simelton, E.; Le, T.T.; Pham, T.V.; Do, T.H. Native and endangered timber tree species in home gardens of Northeast and Northcentral Vietnam. Biodivers. Int. J. 2018, 2, 40-43. [CrossRef]

30. Landon-Lane, C. Livelihoods Grow in Gardens-Diversifying Rural Income through Home Garden; Food and Agriculture Organization of the United Nations: Rome, Italy, 2011. 
31. Galhena, D.H.; Mikunthan, G.; Maredia, K.M. Home gardens for enhancing food security in Sri Lanka. Farming Matters 2012, 28, 12 .

32. Helen Keller International. Homestead food production model contributes to improved household food security, nutrition and female empowerment-Experience from scaling-up programs in Asia (Bangladesh, Cambodia, Nepal and Philippines). Nutr. Bull. 2010, 8, 1-8.

33. Park, J.H.; Woo, S.Y.; Kwak, M.J.; Lee, J.K.; Leti, S.; Soni, T. Assessment of the Diverse Roles of Home Gardens and Their Sustainable Management for Livelihood Improvement in West Java, Indonesia. Forests 2019, 10, 970. [CrossRef]

34. Galhena, D.H. Home Gardens for Improved Food Security and Enhanced Livelihood in Northern Sri Lanka. Ph.D. Thesis, Michigan State University, East Lansing, MI, USA, 2012.

35. Vu, T.M.; Izuno, K.M.; Unakawa, S.F.; Hinjo, H.S.; Anaka, U.T.; Le, V.A. Home garden practices and crop contribution to livelihood in mountainous villages of Central Vietnam. Trop. Agric. Dev. 2015, 59, 118-126. [CrossRef]

36. Timsuksai, P.; Tien, N.D.; Rambo, A.T. Homegardens of the Cao Lan, a tai-speaking ethnic minority in Vietnam's Northern Mountains. Southeast Asian Stud. 2015, 4, 365-383. [CrossRef]

37. Nguyen, D.V.; Nguyen, H.S. Đánh giá tổng hợp hiệu quả của các mô hình nông lâm kết hợp theo hướng phát triển bền vững dọc hành lang đường hồ chí minh đoạn qua a lưới, tỉnh Thừa Thiên Huế. Tạp chí khoa học đại học su phạm thành phố Hồ Chí Minh 2013, 47, 67-75.

38. Ha, M.T.; Nguyen, M.T.; Khuat, T.T.H.; Nguyen, H. Tác động của biến đổi khí hậu đến nông nghiệp và các sáng kiến thích ứng với biến đổi khí hậu tại huyện văn bàn, tỉnh Lào Cai. TNU J. Sci. Technol. 2019, 201, 115-120.

39. Ha, M.T.; Ha, V.L.; Hoang, T.T.H.; Pham, T.H.; Khuat, T.T.H.; Pham, H.Q. Xác định một số mô hình sản xuất thích ứng biến đổi khí hậu tiềm năng tại xã bình long, huyện võ nhai, tỉnh thái nguyên. TNU J. Sci. Technol. 2020, 225, 113-118.

40. Mulia, R.; Nguyen, M.P. Diversity of Agroforestry Practices in Vietnam; World Agroforestry (ICRAF) Vietnam, World Agroforestry (ICRAF) Southeast Asia Regional Program: Hanoi, Vietnam, 2021.

41. World Bank. Rural Population, Percent in Asia. Available online: https://www.theglobaleconomy.com/rankings/rural_ population_percent/Asia / (accessed on 21 January 2022).

42. General Statistic Office of Vietnam. Infographic Dân Số, Lao Động và Việc Làm Năm 2020. Available online: https:/ / www.gso.gov. vn/du-lieu-va-so-lieu-thong-ke/2021/01/infographic-dan-so-lao-dong-va-viec-lam-nam-2020/ (accessed on 21 January 2022).

43. United Nations. The National Action Plan for the Implementation of the 2030 Sustainable Development Agenda. Available online: https:/ / vietnam.un.org/index.php/en/4123-national-action-plan-implementation-2030-sustainable-development-agenda (accessed on 10 October 2021).

44. Abraham, M.; Pingali, P.L. Transforming smallholder agriculture to achieve the SDGs. In The Role of Smallholder Farms in Food and Nutrition Security; Paloma, S.G., Riesgo, L., Louhichi, K., Eds.; Springer: Cham, Switzerland, 2020.

45. FAO. Office of Climate Change, Biodiversity and Environment; FAO: Rome, Italy, 2020.

46. Ferre, M.G. Sustainable Food Systems and Gender Equality in the Context of Climate Change and Biodiversity Conservation; UN Women: Valencia, Spain, 2021.

47. Tran, C.T. Overview of Agricultural Policies in Vietnam; Institute of Policies and Strategy for Agriculture and Rural Development: Hanoi, Vietnam, 2013.

48. OECD. Agricultural Policy Monitoring and Evaluation; Organisation for Economic Cooperation and Development: Paris, France, 2020.

49. World Bank; MPI. Vietnam 2035: Toward Prosperity, Creativity, Equity, and Democracy; World Bank and Ministry of Planning and Investment of Vietnam: Washington, DC, USA, 2016.

50. Marsh, A. Diversification by Smallholder Farmers: Vietnam Robusta Coffee; Food and Agriculture Organization of the United Nations: Rome, Italy, 2007.

51. Hoang, X.D.; Do, T.T.T. Investment in agriculture in recent times: The case of Vietnam. In New Trends and Challenges for Agriculture in the Mekong Region: From Food Security to Development of Agri-Businesses; Sakata, S., Ed.; Bangkok Research Center: Bangkok, Thailand, 2019.

52. World Bank. Transforming Vietnamese Agriculture: Gaining More from Less; World Bank: Washington, DC, USA, 2016.

53. Nguyen, V.G. Vietnam's Agricultural and Rural Development Policies Center on Farmers' Welfare. Available online: https:// vietnamlawmagazine.vn/vietnams-agricultural-and-rural-development-policies-center-on-farmers-welfare-4884.html (accessed on 9 December 2021).

54. Phan, H.S.; Phan, T.V.; Nguyen, L.T.; Nguyen, T.T.X. Review and evaluation of agricultural policies in years 2015-2017. J. Econ. Trade Mark. Manag. 2019, 1, 70-93. [CrossRef]

55. Vu, H.A. OECD Review of Agricultural Policies in Vietnam. Available online: http://apip-apec.maff.go.jp/members/2014/06/ 20/files/18_Ms.Anh.pdf (accessed on 9 December 2021).

56. Nguyen, V.G. Vietnam's Agricultural Sector at a Crossroads. Available online: https://www.eastasiaforum.org/2019/11/28 / vietnams-agricultural-sector-at-a-crossroads / (accessed on 9 December 2021).

57. Dao, T.A.; Nguyen, V.B. Overview of Vietnam's Recent Agricultural and Rural Development Policy. Available online: https: / / ap.fftc.org.tw/article/1422 (accessed on 9 December 2021).

58. JICA. Agricultural Transformation and Food Security 2040. Vietnam Country Report; Japan International Cooperation Agency: Hanoi, Vietnam, 2013. 
59. Barry, D.; Rosa, H. Environmental degradation and development options. In Economic Policy for Building Peace: The Lessons of El Salvador; Boyce, J., Ed.; Lynne Rienner Publishers: Boulder, CO, USA, 1996.

60. Collins, W.W.; Qualset, C.O. Biodiversity in Agroecosystems; CRC Press: Boca Raton, FL, USA, 1999.

61. Mendez, V.E. An assessment of tropical homegardens as examples of local sustainable agroforestry systems. In Agroecosystem Sustainability: Developing Practical Strategies; Gliessman, S., Ed.; CRC Press: Boca Raton, FL, USA, 2000.

62. Shimrah, T.; Lungleng, P.; Shimrah, C.; Khuman, Y.S.C.; Varah, F. Role of traditional homegardens in biodiversity conservation and socioecological significance in Tangkhul community in Northeast India. Trop. Ecol. 2018, 59, 533-539.

63. Giles, J.; Grosjean, G.; Le Coq, J.F.; Huber, B.; Le Bui, V.; Läderach, P. Barriers to Implementing Climate Policies in Agriculture: A Case Study From Viet Nam. Front. Sustain. Food Syst. 2021, 5, 25. [CrossRef]

64. Trung, N.D.; Thang, N.T.; Anh, L.H.; Babu, T.S.A.; Sebastian, L. Analysing the challenges in implementing Vietnam's NationallyDetermined Contribution (NDC) in the agriculture sector under the current legal, regulatory and policy environment. Cogent Environ. Sci. 2020, 6, 1792670. [CrossRef]

65. Ivanic, M.; Martin, W. Implications of higher global food prices for poverty in low-income countries. Agric. Econ. 2008, 39, 405-416. [CrossRef]

66. Swinnen, J.; Squicciarini, P. Mixed Messages on Prices and Food Security. Science 2012, 335, 405-406. [CrossRef] [PubMed]

67. Presidential Task Force on National Food Production. Food Production National Program 2016-2018. Available online: https: / / www.agrimin.gov.lk/web/images/pdf/FoodProductionBook-English.pdf (accessed on 12 December 2021).

68. Le, T.T.; Simelton, E. Portfolio of CSA Practices for Scaling; World Agroforestry (ICRAF): Hanoi, Vietnam, 2018.

69. La, N.; Pham, H.T.; Do, V.H.; Do, T.H.; Tran, H.M.; Vu, T.H.; Nguyen, V.T. Agroforestry Technical Manual. Option: Macadamia-CoffeeSoybeans; World Agroforestry (ICRAF): Hanoi, Vietnam, 2019.

70. La, N.; Pham, H.T.; Do, V.H.; Do, T.H.; Tran, H.M.; Vu, T.H.; Nguyen, V.T. Agroforestry Technical Manual. Option: Teak-Plum-CoffeeSoybeans-Forage Grass; World Agroforestry (ICRAF): Hanoi, Vietnam, 2019.

71. MARD. Good Agricultural Practice for Robusta Coffee Production; Ministry of Agriculture and Rural Development and National Agricultural Extension Centre: Dak Lak, Vietnam, 2017.

72. Kuit, M.; Jansen, D.M.; Nguyen, V.T. Manual for Arabica Cultivation; Tan Lam Agricultural Product Joint Stock Company: Quang Tri, Vietnam, 2004.

73. FAO. TAPE: Tool for Agroecology Performance Evaluation 2019_Process of Development and Guidelines for Application. Test Version; Food and Agriculture Organization of the United Nations: Rome, Italy, 2019.

74. IFPRI. Women's Empowerment in Agriculture Index; International Food Policy Research Institute: Washington, DC, USA, 2012.

75. IFPRI. Instructional Guide on the Abbreviated Women's Empowerment in Agriculture Index (A-WEAI); International Food Policy Research Institute: Washington, DC, USA, 2015.

76. Tzouramani, I.; Mantziaris, S.; Karanikolas, P. Assessing sustainability performance at the farm level: Examples from Greek agricultural systems. Sustainability 2020, 12, 2929. [CrossRef]

77. Reytar, K.; Hanson, C.; Henninger, N. Indicators of Sustainable Agriculture: A Scoping Analysis; World Resources Institute: Washington, DC, USA, 2014.

78. OECD. Environmental Indicators for Agriculture: Methods and Results; Organisation for Economic Cooperation and Development: Paris, France, 2001.

79. Królczyk, J.B.; Latawiec, A.E. Sustainability indicators for agriculture in the European union. In Sustainability Indicators in Practice; Latawiec, A., Agol, D., Eds.; De Gruyter: Warsaw, Poland, 2015; pp. 182-204. ISBN 9783110450507.

80. Nguyen, V.M. VAC and Permaculture in Vietnam. In Proceedings of the Sixth International Permaculture Conference and Convergence, Perth, Australia, 24 September-4 October 1996; Permaculture Association of Western Australia Inc.: Perth, Australia; Karrinyup, Australia, 1997.

81. Sexsmith, K.; Smaller, C.; Speller, W. How to Improve Gender Equality in Agriculture; International Institute for Sustainable Development: Winnipeg, MB, Canada, 2017.

82. Acevedo, M.; Pixley, K.; Zinyengere, N.; Meng, S.; Tufan, H.; Cichy, K.; Bizikova, L.; Isaacs, K.; Ghezzi-Kopel, K.; Porciello, J. A scoping review of adoption of climate-resilient crops by small-scale producers in low- and middle-income countries. Nat. Plants 2020, 6, 1231-1241. [CrossRef]

83. MARD. Vietnam adds 3200 new OCOP Products This Year. Available online: https://www.mard.gov.vn/en/Pages/vietnamadds-3-200-new-ocop-products-this-year.aspx (accessed on 23 January 2022).

84. Office for Coordination of the National Target Program for New Rural Development OCOP. Available online: http:/ / nongthonmoi. gov.vn/Pages/ocop--a-boost-for-rural-economy.aspx (accessed on 23 January 2022).

85. Nguyen, B.L.; Le, D.T. Hiện trạng mô hình nông lâm kết hợp ở huyện Phù Ninh, tỉnh Phú Thọ. In Proceedings of the Hội nghị khoa học toàn quốc về sinh thái và tài nguyên sinh vật lần thứ 7, Hanoi, Vietnam, 20 October 2017; pp. 1669-1677.

86. Timsuksai, P.; Rambo, A.T. The influence of culture on agroecosystem structure: A comparison of the spatial patterns of homegardens of different ethnic groups in Thailand and Vietnam. PLoS ONE 2016, 11, e0146118. [CrossRef] 